\title{
Root spatial distribution and biomass partitioning in Quercus robur $L$. seedlings: the effects of mounding site preparation in oak plantations
}

\author{
Andreas Bolte • Magnus Löf
}

Received: 19 August 2009/Revised: 11 December 2009/ Accepted: 15 January 2010/Published online: 16 February 2010

(C) The Author(s) 2010. This article is published with open access at Springerlink.com

\begin{abstract}
In a reforestation field experiment undertaken in southern Sweden and planted with pedunculate oak, three site preparation treatments (herbicide application $(\mathrm{H})$, mounding site preparation (MSP) and combined herbicide and mounding treatment $(\mathrm{H}+\mathrm{MSP})$ ) were compared to an undisturbed control (C). We analysed root spatial and biomass distribution in 48 harvested seedlings. Compared to the control, both MSP and $\mathrm{H}$ treatments resulted in a significantly higher root system biomass (means C: $16.4 \mathrm{~g}$, H: $45.7 \mathrm{~g}$, MSP: $41.4 \mathrm{~g}, \mathrm{MSP}+\mathrm{H}$ : $102.2 \mathrm{~g}$ ). The proportion of lateral root biomass increased from $38 \%$ (C) to $62 \%(\mathrm{MSP}+\mathrm{H})$, while the two remaining treatments $(\mathrm{H}$, MSP) attained percentages of $48 \%$ and $51 \%$, respectively. The treatments did not alter seedlings' allometry and root:shoot ratio significantly. However, biomass distribution of different root system parts varied among treatments, so that lateral root biomass increased relative to leaf biomass from $\mathrm{C}$ to MSP $+\mathrm{H}$ variant. Site preparation treatments (MSP, MSP $+\mathrm{H}$ ) increased the horizontal extension
\end{abstract}

Communicated by A. Merino.

\section{A. Bolte $(\square)$}

Johann Heinrich von Thünen-Institut (vTI), Federal Research Institute for Rural Areas, Forestry and Fisheries, Institute of Forest Ecology and Forest Inventory, Alfred-Möller-Straße 1, 16225 Eberswalde, Germany

e-mail: andreas.bolte@vti.bund.de

A. Bolte

Burckhardt-Institute, Department Silviculture and Forest Ecology of the Temperate Zones, University Göttingen, Büsgenweg 1, 37077 Göttingen, Germany

M. Löf

Swedish University of Agricultural Sciences, Southern Swedish Forest Research Centre, P.O. Box 49, 23053 Alnarp, Sweden of root biomass, compared to $\mathrm{C}$ and $\mathrm{H}$ variants. We conclude that mounding site preparation is an efficient method for the reforestation of pedunculate oak stands. Due to the comparative positive effects on root system development, MSP presents an alternative to herbicide treatment, particularly at sites where the use of chemicals is restricted.

Keywords Pedunculate oak · Herbicide .

Site preparation - Root collar diameter .

Lateral root length · Root system biomass · Allometry ·

Root:shoot ratio

\section{Introduction}

Oaks (Quercus ssp.) are major components of European temperate vegetation types, and oak forests previously covered larger areas than today (Bradshaw and Lindbladh 2005). For Europe, climate models project prolonged, and more frequent summer droughts in areas such as southern Scandinavia, central Europe and the Mediterranean, and an increased frequency of major storm events (Schär et al. 2004; Luterbacher et al. 2004; Leckebusch et al. 2006; Christensen and Christensen 2007; IPCC 2007). Oaks are among the most wind-stable and drought-tolerant tree species (Ellenberg 1988; von Lüpke and Spellmann 1999). Like other broadleaved tree species, they may become more competitive than several conifers like Norway spruce (Picea abies) and can attain higher production potentials due to increased air temperature and prolonged growing seasons (Koca et al. 2006). Thus, oaks are a preferred tree genus in any adaptation strategies to climate change for both ecological and economic reasons in these regions, and the oak forest area may increase in the future (Berg et al. 1994; Larsen 1995). 
Oaks are normally cultivated on fertile sites, where the natural herb and shrub vegetation is abundant and interferes strongly with newly planted tree seedlings (Löf 2000). Moreover, herbaceous vegetation on regeneration sites provides an environment suitable for voles, which may damage seedlings. The consequent low survival and poor growth of seedlings may result in substantial economic losses in forest management. Therefore, vegetation control on open sites during reforestation is needed and is usually achieved by using herbicides, mechanical site preparation, mulching or prescribed burning (e.g. Davies 1988; Dey et al. 2008). Due to their relatively high effectiveness combined with low cost, herbicides are often preferred. However, increased environmental awareness has urged a discussion on available alternatives (Willoughby et al. 2009). Mounding site preparation, i.e. inverted mounds on humus to create elevated planting spots, is an old mechanical site preparation technique that again is attracting attention (Sutton 1993). It presents an alternative, especially in boreal coniferous forest sites, where low soil temperature, high water table and competing herb vegetation are serious problems (Hawkins et al. 1995; Hallsby and Örlander 2004; Pennanen et al. 2005). Less research has been done on mounding site preparation in temperate zones for broadleaved species (Dey et al. 2008). Though results of several root studies provide insight into the rooting behaviour of oaks seedlings in competition with herbaceous and grass vegetation (e.g. Harmer and Robertson 2003; Collet et al. 2006), we lack knowledge about the effects of mechanical site preparation on root system characteristics for oak seedlings. Since root development plays a major role in competition among tree individuals (e.g. Leuschner et al. 2004; Bloor et al. 2008) and in competition between young trees and herbaceous vegetation for limited soil resources (Löf 2000; Coll et al. 2003 , 2004), information about biomass partitioning to roots and root system extension forms the basis for appropriate evaluations of regeneration success.

The present study was conducted on a temperate forest site in southernmost Sweden to increase the efficiency of oak stand establishment. Following our discussion of growth and survival (Löf et al. 2006), this paper focuses on seedling root development in mounding site preparation treatments with and without herbicide application. The specific objectives of this study were (1) to analyse whether herbicide and mounding site preparation treatments changed seedling allometry and biomass partitioning in various plant compartments above and below ground, (2) to examine treatment effects on the horizontal and vertical root system extension and (3) to evaluate any benefits of mounding site preparation with or without herbicide application on seedling development.

\section{Materials and methods}

Site and experimental design

The study was conducted in the Skarhult experimental forest $\left(55^{\circ} 50^{\prime} \mathrm{N} / 13^{\circ} 24^{\prime} \mathrm{E}, 90 \mathrm{~m}\right.$ a.s.l.), Scania (southern Sweden), which has been subjected to wind-throw damage. The 4.3 ha study site comprised a 32-year-old hybrid larch (Larix * eurolepis Henry) stand planted in 1970, which replaced a European beech (Fagus sylvatica L.) stand damaged by wind-throw in 1967, and which subsequently was wind-thrown in December 1999.

The mean monthly temperature and precipitation at Lund, $15 \mathrm{~km}$ west of Skarhult, ranged from -0.3 to $17.9^{\circ} \mathrm{C}$ and from 67 to $87 \mathrm{~mm}$ in January and July, respectively. During the study, no extreme low or high precipitation periods occurred (Anonymous 2002-2004).

Soil type was a gleyic cambisol (Gleyic B., FAO 1988, Table 1) developed from loose moraine sediments. A sandy loam soil texture prevailed to a depth of $60 \mathrm{~cm}$ with a $25-43 \%$ sand, $40-50 \%$ silt and $17-25 \%$ clay content (Ad-hoc-AG Boden 2005). The potential tree rooting zone is seasonally water saturated as the height of the groundwater table varies from 40 to $60 \mathrm{~cm}$ depth.

Soil fertility was classified as moderate with a medium $\mathrm{C} / \mathrm{N}$ ratio (Table 1). The soil was acidic with a moderate to low cation exchange capacity (CEC) and a moderate CEC saturation of the base cations $\mathrm{K}, \mathrm{Mg}$ and $\mathrm{Ca}$.

Table 1 Chemical soil properties of the organic layer and the rooted mineral soil

\begin{tabular}{lllccc}
\hline & $\mathrm{pH}(\mathrm{KCL})$ & $\mathrm{C} / \mathrm{N}$ ratio & $\mathrm{CEC}\left(\mu \mathrm{eq} \mathrm{g}{ }^{-1}\right)$ & $\mathrm{Al}(\% \mathrm{CEC})$ & $\mathrm{K}+\mathrm{Ca}+\mathrm{Mg}(\% \mathrm{CEC})$ \\
\hline Oh (organic layer) & 4.2 & 17.8 & - & - & - \\
Ah (min. soil 0-10 cm) & 3.8 & 17.9 & 71 & 63.7 & 17.4 \\
Bv (min. soil 10-27 cm) & 4.1 & - & 30 & 84.9 & 8.6 \\
Bv-Go (min. soil 27-58 cm) & 4.1 & - & 24 & 87.0 & 7.8 \\
\hline
\end{tabular}

$O h$ humified organic layer containing amorphous organic material, $A h$ humified mineral top soil horizon, $B v$ cambic mineral soil horizon, $B v-G o$ cambic/gleyic mineral soil horizon (AK Standortskartierung 1996), $C E C$ effective cation exchange capacity, $A l$ exchangeable aluminium ions, $K+C a+M g$ sum of exchangeable base cations 
A randomised block experimental design was adopted on the fenced experimental site comprising four blocks each with four variants: herbicide $(\mathrm{H})$, mounding site preparation (MSP), mounding site preparation plus herbicide $(\mathrm{MSP}+\mathrm{H})$ and untreated control $(\mathrm{C})$. The blocks were $27 \times 25 \mathrm{~m}(0.067 \mathrm{ha})$ in size, spaced $4 \mathrm{~m}$ apart and were located approx. $20 \mathrm{~m}$ from the nearest forest edge. At the end of April 2002, each variant was planted with 25 bare-root pedunculate oak seedlings (Quercus robur L., $1 / 0,15-25 \mathrm{~cm}$, Visingsö-Herrängen, southern Sweden, $58^{\circ} 02^{\prime} \mathrm{N} / 14^{\circ} 19^{\prime} \mathrm{E}, 110 \mathrm{~m}$ a.s.l.) in three randomly placed rows $1 \mathrm{~m}$ apart using a planting spade. The provenance from Visingsö is considered of high quality, but initially different seed sources from southern Sweden was used to establish this stand in 1865, why the exact seed origin is rather blurred. The distance between rows and treatments was approx. $2 \mathrm{~m}$. The mounding site preparation treatments (MSP), also called bedding (Sutton 1993), were prepared in early April 2002, with an excavator forming approx. $25 \mathrm{~m}$ long, $2 \mathrm{~m}$ wide and $20 \mathrm{~cm}$ high inverted mounds on humus. In the herbicide treatments $(\mathrm{H})$, glyphosate $\left(0.3 \mathrm{~g} \mathrm{~m}^{-2}\right.$ active gradient $)$ was applied in early June and mid-July during the 2002, 2003 and 2004 growing seasons. The herbicide was applied in strips approx. $25 \mathrm{~m}$ long and $1 \mathrm{~m}$ wide along the planting rows alongside the seedlings.

Root extractions and additional assessments

In early December 2004, three growing seasons after commencement of the experiment, three oak seedlings were selected from each block (no. 5, 6 and 7 in the first row). The root collar $\left(d_{0}\right)$ was marked to indicate northerly direction on the shoot and the boundary between the aboveand below-ground plant compartments. Thereafter, we extracted carefully the entire root systems with coarse and fine root parts by digging and manually removing soil material around the roots using small hand tools. The root systems were washed under running water in the field, and the length and orientation of the three longest roots were recorded for each seedling. In the laboratory, the root systems were divided into sections representing (1) horizontal $10 \mathrm{~cm}$ distance classes from stem axis, (2) vertical $10 \mathrm{~cm}$ distance classes from soil surface and (3) four ordinal classes of root system orientation, i.e. NE, SE, SW and NW (Fig. 1). The remaining stump part located below ground was analysed separately. The dry mass component of the seedling stem and the roots in each section was determined after drying at $70^{\circ} \mathrm{C}$ for $72 \mathrm{~h}$. In addition, data for the above-ground seedling components of leaf and stem biomass, used for reference purposes in the analyses, were derived according to the methods described in Löf et al.

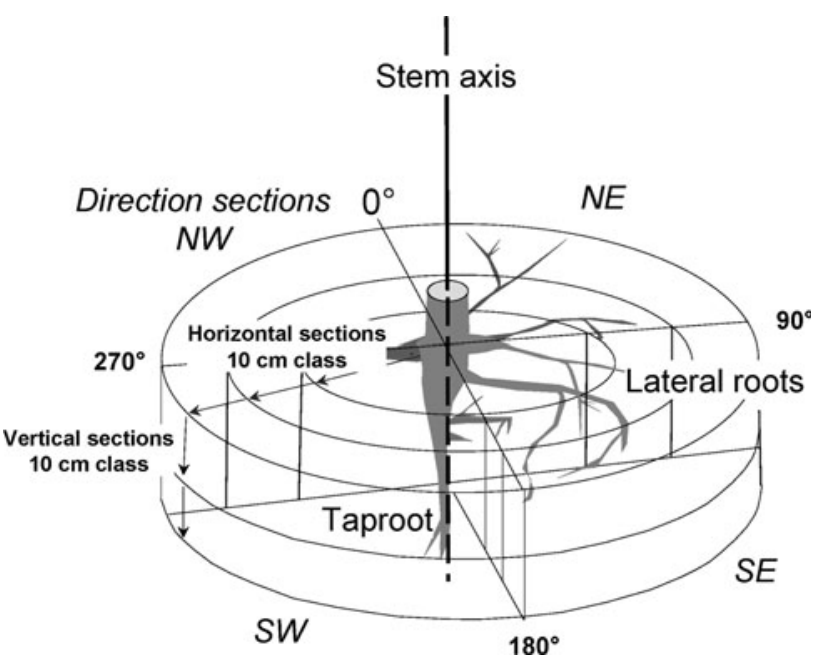

Fig. 1 Schematic illustration showing the framework for recording coarse root dimensions, based on the horizontal and vertical sectioning of the root systems

(2006). Leaves from the seedlings were sampled at the end of September 2004.

Data analysis and distribution modelling

Allometry assessments were performed to describe the relationships between root collar diameter (RCD) and the root structural traits of maximum lateral root length (MRL) or dry weight of total root system biomass (TRB). A linear function (Eq. 1) was fitted with a simple least square regression using transformed variables (cf. Le Goff and Ottorini 2001; Bolte et al. 2004):

$\ln y=\beta_{0}+\beta_{1} \ln x$,

where $y=$ maximum lateral root length [MRL, $\mathrm{cm}]$ or total root system biomass [TRB, g dry weight]; $x=$ root collar diameter $[\mathrm{RCD}, \mathrm{cm}] ; \beta_{0}, \beta_{1}=$ empirical parameters.

Finney (1941) suggested a bias correction function (Eq. 2) be applied to estimate the bias due to the use of transformed variables in the regression analysis.

$K=e^{s_{\ln }^{2}} / 2\left\{1-\frac{s_{\ln }^{2}}{4 n}\left(s_{\ln }^{2}+2\right)+\frac{s_{\ln }^{4}}{96 n^{2}}\left(3 s_{\ln }^{4}+44 s_{\ln }^{2}+84\right)\right\}$

where $s_{\ln }=$ standard deviation of $\ln$-transformed values $(\ln x, \ln y), n=$ number of samples.

We performed a non-parametric Kruskal-Wallis $H$ test for comparisons of biomass partitioning between the above- and below-ground plant compartments, as well as of root structure data among the different horizontal and vertical sections of the different variants.

Horizontal biomass distribution of sapling root systems was modelled for all treatments separately by fitting 
horizontal section biomass values to a logistic model distribution (Eq. 3); root collar diameter and distance from stem centre were the predictor variables. The first $10 \mathrm{~cm}$ section (0-10 cm distance from stem centre) also included stump biomass below ground. Nielsen and Mackenthun (1991) used a similar model approach for modelling vertical fine root distribution of old-growth Norway spruce and European beech.

$z=\frac{\beta_{0} \cdot x^{\beta_{1}}}{1+\beta_{2} \cdot e^{\left(\beta_{3} \cdot y\right)}}$

where $z=$ root section biomass incl. stump [RSB, g dry weight]; $x=$ root collar diameter $[\mathrm{RCD}, \mathrm{cm}] ; y=$ horizontal distance from stem centre (mean of $10 \mathrm{~cm}$ section) [HD, cm] or soil depth (mean of $10 \mathrm{~cm}$ section) [SD, cm]; $\beta_{0}, \beta_{1}, \beta_{2}, \beta_{3}=$ empirical parameters.

All derived data were stored in a MS Access database. We used Statistica 7.1 (StatSoft Inc. 2005) for all statistical analyses and modelling purposes. In the comparisons, $P<0.05$ was considered significant.

\section{Results}

A positive treatment effect on both root and seedling biomass (cf. Löf et al. 2006) was observed 3 years after the experiment commenced. The combined use of mounding site preparation and herbicide (MSP $+\mathrm{H}$, Table 2) led to a significantly higher above- and below-ground oak biomass, almost six times higher than for the control variant (C). A significantly higher root system biomass was found also in the herbicide application $(\mathrm{H})$ and the site preparation treatment (MSP). This increase was less clear for aboveground biomass and different root system fractions (lateral roots, tap roots). Differences between H and MSP treatments were small. The proportion of lateral roots of the entire root system biomass rose from $38 \%$ (C) to $62 \%$
$(\mathrm{MSP}+\mathrm{H})$. The herbicide $(\mathrm{H})$ and site preparation (MSP) treatments attained similar values of $48 \%$ and $51 \%$, respectively.

Allometric relationships were found between root collar diameter (RCD) and either total root system biomass (TRB, dry weight) or maximum lateral root length (MRL) for all pedunculate oak saplings (Table 3, Fig. 2a, b). Linear regression functions obtained from log-transformed data [Eq. (1)] attained medium to high coefficients of determination. The residuals are normally distributed according to a Shapiro-Wilk normality test $(P<0.05)$. No clear indication was found of a difference in relationships between the different site preparation treatments (Fig. 2a, b).

Moreover, treatment effects on biomass distribution patterns between above- and below-ground plant compartments were less obvious, and even inconsistent for total biomass or plant fractions. Whereas the root:shoot ratio was not affected significantly by the different treatments compared to control (Fig. 3, cf. Löf et al. 2006), and remained quite constant over the entire root biomass spectrum (Fig. 4a), biomass partitioning to lateral roots increased relative to partitioning to leaves along the gradient from control (C) to mounding site preparation combined with herbicide application (MSP $+\mathrm{H}$, Fig. 4b). This resulted in a significant difference in biomass ratios of lateral root to leaf fractions when comparing the most intensive treatment $(\mathrm{MSP}+\mathrm{H})$ with the control (C, Fig. 3).

Analyses of the root system orientation revealed no significant variation in root system biomass in the four ordinal direction classes (NE, SE, SW, NW; KruskalWallis test, control: $P=0.07$; MSP: $P=0.19$; H: 0.80 ; MSP $+\mathrm{H}:$ 0.52), and thus no root anisotropy. Therefore, all direction classes were merged for further analyses of spatial root distribution.

Horizontal root system extension and biomass distribution varied between the different treatments. In the

Table 2 Root system and biomass distribution traits of the oak seedlings $(n=48)$

\begin{tabular}{|c|c|c|c|c|}
\hline & \multicolumn{4}{|l|}{ Treatment } \\
\hline & $\mathrm{C}$ & $\mathrm{H}$ & MSP & $\mathrm{MSP}+\mathrm{H}$ \\
\hline Max. lateral root length* $(\mathrm{cm})$ & $29.8^{\mathrm{a}} \pm 8.8$ & $42.6^{\mathrm{a}} \pm 11.9$ & $38.8^{\mathrm{a}} \pm 8.7$ & $49.8^{\mathrm{b}} \pm 11.0$ \\
\hline Lateral roots $(\mathrm{g})$ & $6.3^{\mathrm{a}} \pm 5.8$ & $22.1^{\mathrm{a}, \mathrm{b}} \pm 16.5$ & $20.9^{\mathrm{b}} \pm 12.1$ & $63.4^{\mathrm{b}} \pm 46.3$ \\
\hline Taproot (g) & $10.1^{\mathrm{a}} \pm 5.5$ & $23.7^{\mathrm{b}} \pm 13.4$ & $20.5^{\mathrm{a}} \pm 10.9$ & $38.8^{\mathrm{b}} \pm 12.3$ \\
\hline Total root system biomass ( $\mathrm{g}$ ) & $16.4^{\mathrm{a}} \pm 8.0$ & $45.7^{b} \pm 29.3$ & $41.4^{\mathrm{b}} \pm 18.9$ & $102.2^{\mathrm{c}} \pm 46.5$ \\
\hline Total biomass above ground (g) & $29.9^{\mathrm{a}} \pm 28.8$ & $69.6^{\mathrm{a}} \pm 44.3$ & $72.4^{\mathrm{a}, \mathrm{b}} \pm 42.6$ & $173.4^{\mathrm{b}} \pm 84.1$ \\
\hline Total biomass (g) & $46.2^{\mathrm{a}} \pm 36.3$ & $115.3^{\mathrm{a}} \pm 73.0$ & $113.8^{\mathrm{a}} \pm 60.3$ & $275.6^{\mathrm{b}} \pm 126.7$ \\
\hline
\end{tabular}

Mean values $\pm S D$ are displayed. Means followed by different letters $(\mathrm{a}, \mathrm{b}$ or $\mathrm{c})$ resulted in significant differences between treatments $(P<0.05$, Kruskal-Wallis $H$ test); treatment description: $C$ control, $H$ herbicide application, $M S P$ mounding site preparation, $M S P+H$ combination of mounding site preparation and herbicide application

* Mean of the three longest lateral roots 
Table 3 Regression equations for predicting root structural traits from root collar diameter $(R C D)$

\begin{tabular}{lcr}
\hline Root collar diameter [RCD] & Total root system biomass [TRB] & Max. lateral root length [MRL] \\
\hline$\beta_{0} \pm S E$ & $-2.29 \pm 0.34$ & $1.72 \pm 0.24$ \\
$\beta_{1}[\ln R C D] \pm S E$ & $2.06 \pm 0.12$ & $0.67 \pm 0.08$ \\
$N$ & 48 & 48 \\
$R^{2}$ & 0.87 & 0.59 \\
$S$ & 0.30 & 0.21 \\
$K$ & 1.04 & 1.02 \\
\hline
\end{tabular}

All equations are of the form $\ln y=\beta_{0}+\beta_{1} \ln x$, see Eq. (1), $y=$ total root system biomass (TRB, g) or $y=$ maximum lateral root length (MRL, $\mathrm{cm}), x=$ root collar diameter $(R C D, \mathrm{~cm}), \beta_{0}, \beta_{1}=$ regression coefficients (empirical parameters, rounded to two decimals) with standard errors in parentheses $( \pm S E) . R^{2}=$ coefficient of determination $\left(R^{2}\right), s=$ standard deviation of residuals ("standard error" of estimation) and $K=$ bias correction factor, see Eq. (2), are displayed. All model parameters were statistically significant $(\alpha=0.05)$ in accounting for variation in $R C D$

Fig. 2 Relationships between root collar diameter (ln RCD) and a total root system biomass (ln TRB), b maximal lateral root length (ln MRL). Scatter data are differentiated into different treatments. For descriptions of treatments, see text. The equations of the regression lines are presented in Table 3 (a)

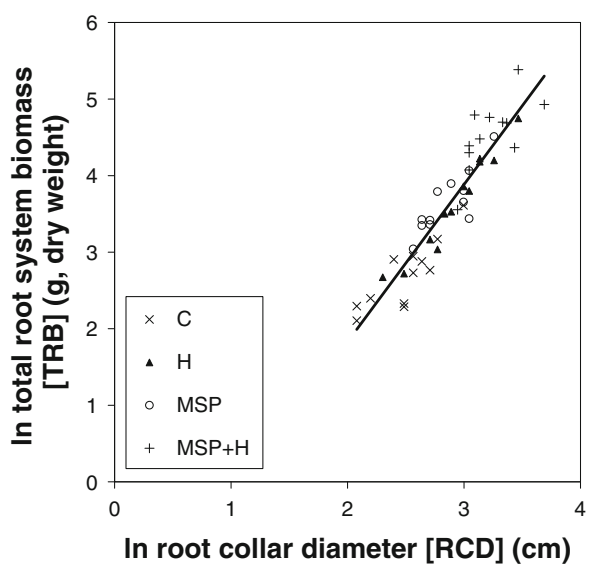

(b)

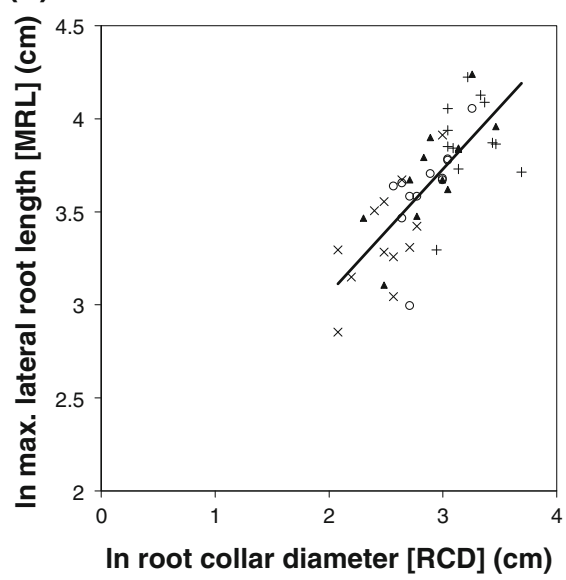

horizontal root distributions modelled from the median seedling $d b h$ (Fig. 5a, b), seedlings in the control (C) and the herbicide treatment $(\mathrm{H})$ exhibited a stem-centred root biomass distribution. In the $\mathrm{C}$ treatment, $83 \%$ of root system biomass was found within $10 \mathrm{~cm}$ of the stem centre, and only small root biomass proportions were found at distances $20 \mathrm{~cm}$ beyond the stem. Seedlings in the $\mathrm{H}$ treatment also showed this rooting pattern $(73 \%$ root biomass $<10 \mathrm{~cm}$ stem distance). In contrast, MSP and $\mathrm{MSP}+\mathrm{H}$ treatments induced a higher biomass partitioning to lateral roots. This resulted in a more extensive root system, and, compared to the $\mathrm{C}$ treatment, higher proportions of root biomass in $>10 \mathrm{~cm}$ distance from stem centre (MSP: 30\%, MSP $+\mathrm{H}: 39 \%$ ) and considerable root biomass at distances up to $30 \mathrm{~cm}$ from stems.

Less variation was found in the general shape of the vertical rooting distribution (Fig. 5c, d). Mean rooting depth increased from $30 \mathrm{~cm}$ in the $\mathrm{C}$ treatment to about $60 \mathrm{~cm}(\mathrm{MSP}+\mathrm{H})$. The treatments with site preparation (MSP) and herbicide application $(\mathrm{H})$ attained similar mean rooting depths of $40 \mathrm{~cm}$ and a comparable vertical rooting distribution.

\section{Discussion}

Mounding site preparation has considerable positive effects on both the size and extension of the root system. This strongly supports previous experimental results (Löf et al. 2006), which focussed on site preparation effects on survival and above-ground performance of seedlings. The results emphasise the applicability of mounding site preparation for efficient reforestation. Similar conclusions have been reached in several previous studies of conifer and broadleaved tree species (Sutton 1993; Gemmel et al. 1996; Nilsson and Örlander 1999; Patterson and Adams 2003; Hallsby and Örlander 2004; Pennanen et al. 2005).

Regarding whole seedling development, less interference from ground vegetation compared to the control (C, vegetation cover 2004: 95.9\%, see Löf et al. 2006) is reputedly the main reason for seedling superiority in repeated herbicide treatments with and without site preparation $(\mathrm{H}$, vegetation cover: $12.4 \%$, MSP $+\mathrm{H}$, vegetation cover: 6.7\%) (e.g. Davies 1988; Löf 2000; Collet et al. 2006). However, in this study, mounding site preparation without herbicide application (MSP) and higher vegetation 


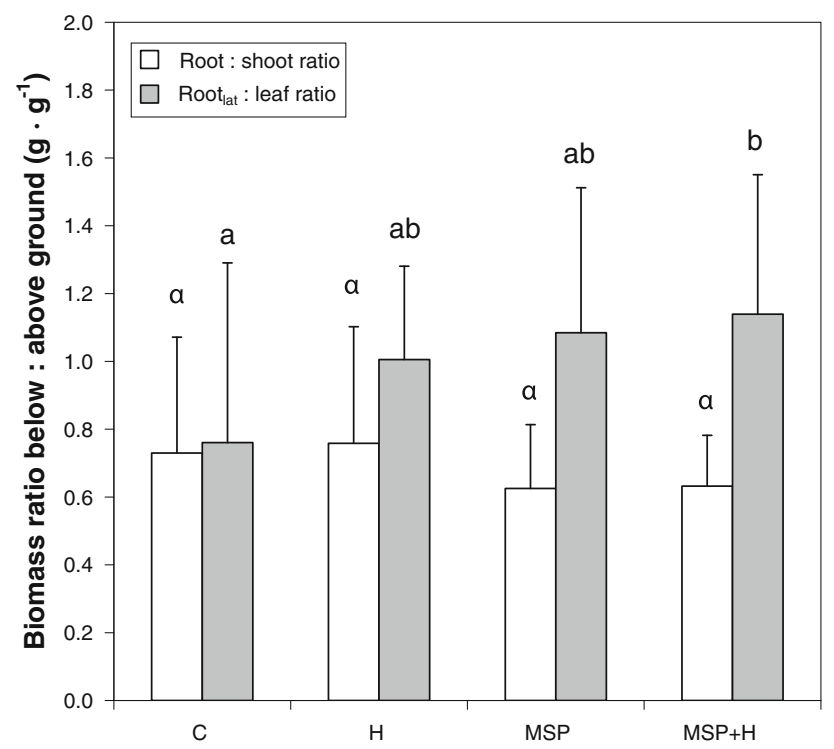

Fig. 3 Biomass ratio below and above ground. Mean \pm S.D. Blank bars: ratio of total root biomass and shoot biomass (root:shoot ratio), grey bars: ratio of lateral root biomass and leaf biomass, in $\mathrm{g} \mathrm{g}^{-1}$, dry weight. Treatments followed by different letters (greek for compared root:shoot ratios, latin for compared sub-fractions) resulted in statistically significant differences $(P<0.05$, Kruskal-Wallis $H$ test). For descriptions of treatments, see text

cover (95.9\%) also resulted in seedling development similar to that in the herbicide treatment $(\mathrm{H}$, Table 2). Moreover, the higher horizontal root extension and higher lateral root biomass compared to the control (C) and the herbicide treatment $(\mathrm{H}$, Fig. 5a, b) indicate a specific effect of the MSP treatment on the seedlings. This is particularly obvious when comparing seedlings with the same root collar diameter (Fig. 5b). Weed reduction in the seedlings' first year, and the improvement in soil conditions by increasing the fine texture, organic matter content and humus mineralisation in the top soil may be the reasons
(Örlander et al. 1990; Carlquist 2000; Löf et al. 2006). Thus oak seedlings seem to follow a root foraging strategy by extending their root system into soil nutrient hot spots (De Kroon and Mommer 2006, p. 114; Grime and Mackey 2002) and into soil areas with fewer roots from competitors (Grime 1979; Bauhus and Messier 1999; Bolte and Villanueva 2006). Moreover, at cool sites with temporary water-logging, like ours, mounding site preparation may increase heat absorption and consequently create better conditions for lateral root growth (Lyr and Garbe 1995; Lyr 1996; Carlquist 2000).

In contrast to MSP seedlings, those treated with herbicides $(\mathrm{H})$ had a significantly higher taproot biomass (Table 2), but both MSP and H seedlings showed similar vertical rooting patterns. Considerably deeper and laterally more extensive rooting was found for seedlings treated with both herbicide $(\mathrm{H})$ and mounding site preparation (MSP; Fig. 5c, d).

As mounding may result in a break down in soil capillarity, when mineral soil is loaded onto humus, dry soil conditions may result and have been reported to influence seedling growth and survival (e.g. Hallsby and Örlander 2004). Although we did not find any low soil water potentials in this study (Löf et al. 2006), particularly dry sites probably should be avoided when using mounding.

Diameter at breast height $(d b h)$, or root collar diameter, commonly is used in tree allometry to estimate root biomass for young trees (e.g. Drexhage and Colin 2001; Le Goff and Ottorini 2001; Hoffmann and Usoltsev 2001; Knapp et al. 2006). A comparison of the results of this study (Table 3) with recent compilations of allometric relationships between trunk size and root system biomass for oak species (Quercus ssp.) (Zianis et al. 2005; Muukkonen and Mäkipää 2006) reveals that similar regression equations demonstrate the consistency of this relationship for oak independent of site and competitive
Fig. 4 Variation in biomass above ground versus biomass below ground; a Root:shoot ratio, i.e. total root system biomass (ln TRB, g, dry weight) versus total biomass above ground (ln TBA, g, dry weight). The displayed regression line and function $(*)$ does not include three outliers with a root:shoot ratio above $1 ; \mathbf{b}$ lateral root biomass (ln $\mathrm{RB}_{\text {lat }}, \mathrm{g}$, dry weight) versus leaf biomass (ln LB, g, dry weight). The regression line and function includes all values. The scattered lines represent the 1:1 ratio for the compared parameters (a)

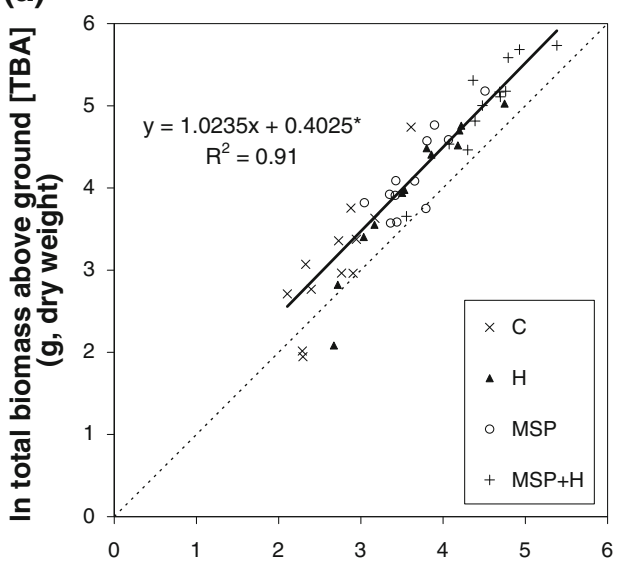

In root system biomass [TRB] (g, dry weight) (b)

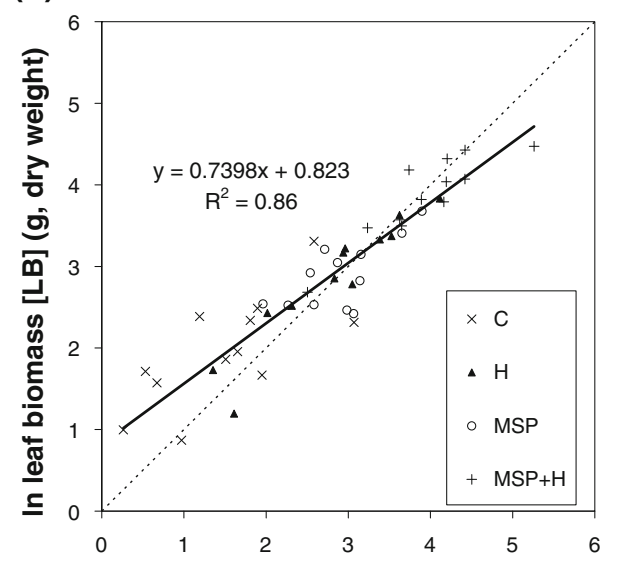

In lateral root biomass $\left[\mathrm{RB}_{\text {lat }}\right]$ (g, dry weight) 
(a)

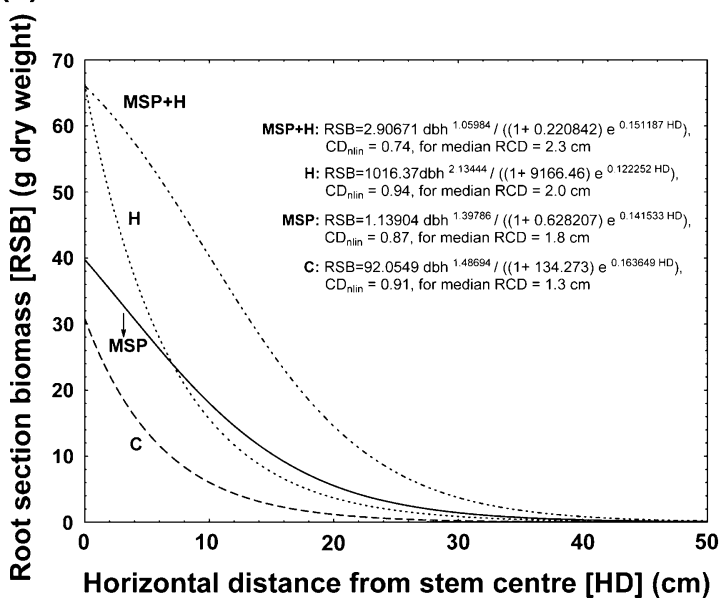

(c) Root section biomass [RSB] (g dry weight)

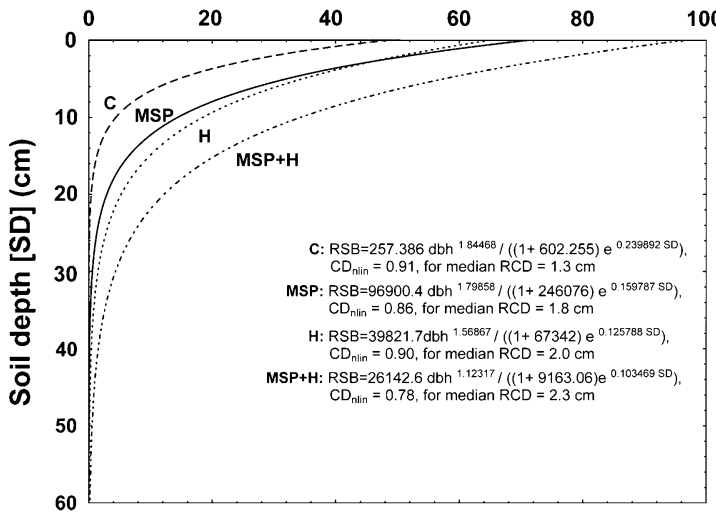

Fig. 5 Modelled spatial distribution of root section biomass [RSB]: (a, b) horizontal rooting; displayed lines represent either saplings' median $R C D$ per each treatment sampling (a) or all saplings' median $R C D=1.85 \mathrm{~cm}(\mathbf{b}) ;(\mathbf{c}, \mathbf{d})$ vertical rooting, displayed lines represent

conditions (cf. Santantonio et al. 1977). This is in accordance with the notion of a 'unifying allometric theory' (Niklas 2004), and hence also with Machado et al. (2003) and Curt et al. (2005) who reported no evidence of variation in biomass partitioning among compartments above and below ground in seedlings of five conifer species and European beech, respectively, due to different soil resource limitations. However, contradicting to this, other authors found recently variations of root-shoot's allometry and biomass partitioning in pine species due to tree age or height (Peichl and Arain 2007) or soil compaction and organic matter removal (Ludovici 2008). Moreover, the reputed alternation of biomass distribution between aerial and non-aerial tree organs, expressed e.g. as a root:shoot ratio, due to changing soil fertility (Axelsson and Axelsson 1986; Keyes and Grier 1981; Paz 2003), varying light regime (Ammer 2003), different interspecific competition regimes (McConnaughay and Coleman 1999; Bolte et al. 2004) and environmental stress (Ericsson et al. 1996) may (b)

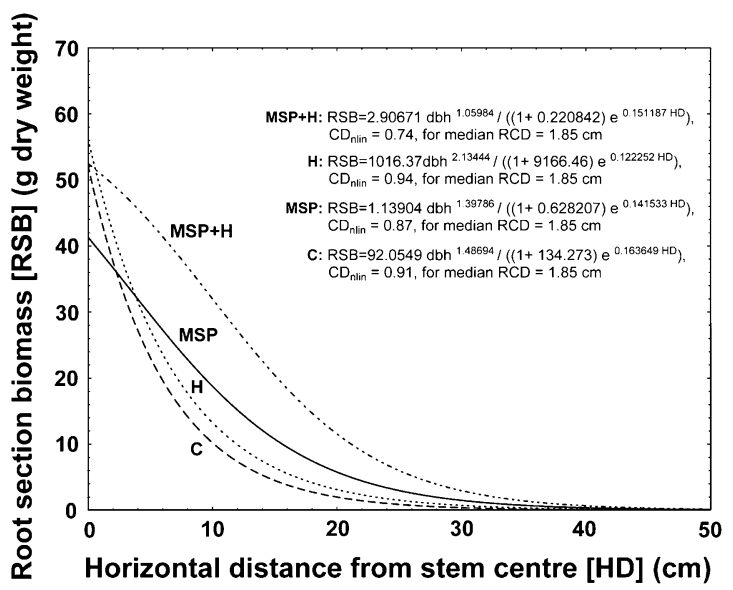

(d) Root section biomass [RSB] (g dry weight)

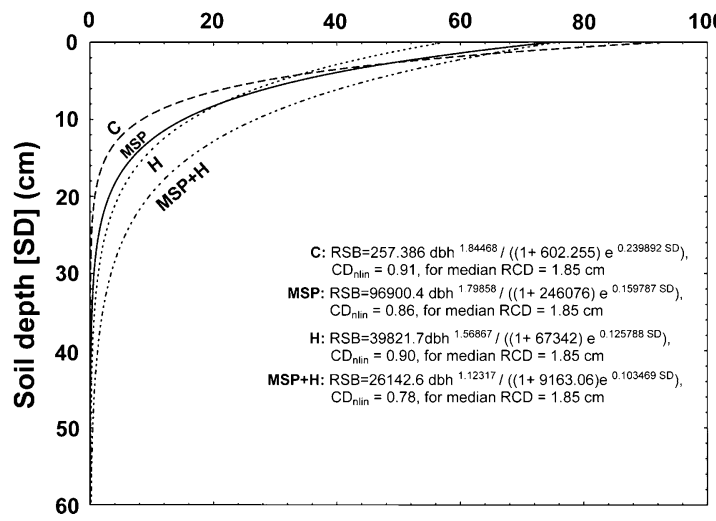

either saplings' median $R C D$ per each treatment sampling (c) or all saplings' median $(\mathbf{d}) ; \mathrm{CD}_{\text {nlin }}$ : Non-linear coefficient of determination. The distributions are results of the fitting to the logistic model distribution shown in Eq. (3)

conflict with this theory. Variations from an assumed functional balance between root and shoot systems are interpreted as adaptations to a resource supply limited by site conditions and competition according to the optimality theory (Bloom et al. 1985; Wilson 1988). However, they can be also the result of ontogenetic drift, and thus may be misinterpreted as plasticity of biomass partitioning (Reich 2002). In the present study, mounding site preparation (MSP) and combined MSP and herbicide treatment $(\mathrm{MSP}+\mathrm{H})$ lowered root:shoot ratios slightly, but not significantly (Fig. 3), compared to control (C), whereas oak seedling size and growth above ground increased remarkably (Löf et al. 2006). Thus, clear signals for an adjustment in oak biomass partitioning to adapt to soil resource limitations arising from grass competition (cf. McConnaughay and Coleman 1999; Collet et al. 2006) or soil compaction (Ludovici 2008) are absent in this study.

The increase in the biomass fraction ratio of lateral root biomass to leaf biomass with intensified treatment 
(Fig. 4b) points to a dominance of biomass repartitioning among root fractions over a biomass partitioning shift between root and shoot systems. This is underlined by the significant rise $(P<0.05)$ in the lateral to total root biomass ratio from the control $(\mathrm{C}: 0.35 \pm 0.22)$ to the combined site preparation-herbicide application treatment (MSP $+\mathrm{H}: 0.57 \pm 0.14$, Table 3 ). In comparison, the ratio of leaf to total shoot biomass was unaffected (C: $0.32 \pm 0.06 ; \mathrm{MSP}+\mathrm{H}: 0.32 \pm 0.04)$. On the one hand, these results suggest that light supply is not the primary resource constraint for oaks and that root competition between the saplings and herbaceous vegetation is more decisive (cf. Löf et al. 2006). This is in line with results from Picon-Cochard et al. (2006) from competition studies between grass vegetation and Scots pine seedlings. On the other hand, our results support Reich's (2002) assumption that the root:shoot ratio is a rather insensitive indicator for phenotypic adaptation to variations in resource supply.

\section{Conclusion}

Our results demonstrate that mounding site preparation is an efficient method for the reforestation of oak stands. After three growing seasons, mounding site preparation was found to have a positive effect on root system and seedling development, similar to that of repeated herbicide application, exceeding the performance of the control seedlings significantly in almost all traits. Plant allometry did not change with different treatments. However, a root biomass repartitioning to the lateral roots, and a more extensive root system point to a higher performance of oak seedling below ground under mounding site preparation compared to repeated herbicide application. Therefore, mounding site preparation is a preferable method at cool sites with a high ground-water table, and particularly at sites, and in areas where ecological vulnerability makes restrictions to chemical use essential. However, attention should be paid to possible nutrient losses arising from enhanced humus mineralisation with possible negative effects on nutrient cycling and ground-water eutrophication.

\footnotetext{
Acknowledgments We are grateful to Ulf Johansson for the assistance at Skarhult experimental forest, Tomasz Czajkowski (Johann Heinrich v. Thünen-Institute), Thomas Kompa and Heiko Rubbert (Göttingen University, Dept. Silviculture and Forest Ecology) for their help with root extractions and root system analyses. This study was funded by the Lidellska foundation, the Swedish Research Council for Environment, Agricultural Sciences and Spatial Planning and the Sustainable Management in Hardwood Forests research program. The root and soil studies were supported by the German Federal Ministry of Science and Technology (Junior Professorship A. Bolte).
}

Open Access This article is distributed under the terms of the Creative Commons Attribution Noncommercial License which permits any noncommercial use, distribution, and reproduction in any medium, provided the original author(s) and source are credited.

\section{References}

Ad-hoc-AG Boden (2005) Bodenkundliche Kartieranleitung. 5th ed. Bundesanstalt für Geowissenschaften und Rohstoffe Hannover, Germany [in German]

Ammer C (2003) Growth and biomass partitioning of Fagus sylvatica L. and Quercus robur L. seedlings in response to shading and small changes in the R/FR-ratio of radiation. Ann For Sci 60:163-171. doi:10.1051/forest:2003009

Anonymous (2002-2004) Väder och vatten. Swedish meteorological and hydrological institute (SMHI) Norrköping, Sweden [in Swedish]

Axelsson E, Axelsson B (1986) Changes in carbon allocation patterns in spruce and pine trees following irrigation and fertilization. Tree Physiol 2(1/3):189-204

Bauhus J, Messier C (1999) Soil exploitation strategies of fine roots in different tree species of the southern boreal forest of eastern Canada. Can J For Res 29(2):260-273. doi:10.1139/cjfr-29-2260

Berg ̊, Ehnström B, Gustafsson L, Hallingbäck T, Jonsell M, Weslien J (1994) Threatened plant, animal, and fungus species in Swedish forests: distribution and habitat associations. Conserv Biol 8(3):718-731. doi:10.1046/j.1523-1739.1994.08030718.x

Bloom AJ, Chapin FS, Mooney HA (1985) Resource limitation on plants-an economic analogy. Ann Rev Ecol Syst 16:363-392

Bloor JMG, Leadley PW, Barthes L (2008) Responses of Fraxinus excelsior seedlings to grass-induced above- and below-ground competition. Plant Ecol 194(2):293-304. doi:10.1007/s11258007-9292-y

Bolte A, Villanueva I (2006) Interspecific competition impacts on the morphology and distribution of fine roots in European beech (Fagus sylvatica L.) and Norway spruce (Picea abies (L.) Karst.). Eur J For Res 125(1):15-26. doi:10.1007/s10342-0050075-5

Bolte A, Rahmann T, Kuhr M, Pogoda P, Murach D, von Gadow K (2004) Relationships between tree dimension and coarse root biomass in mixed stands of European beech (Fagus sylvatica L.) and Norway spruce (Picea abies [L.] Karst.). Plant Soil 264 (1/2):1-11. doi:10.1023/B:PLSO.0000047777.23344.a3

Bradshaw RHW, Lindbladh M (2005) Regional spread and standscale establishment of Fagus sylvatica and Picea abies in Scandinavia. Ecology 86(7):1679-1686. doi:10.1890/03-0785

Carlquist CG (2000) Högen som markbehandlingsmetod vid skogsodling. Del I. Report 67, Department of short rotation forestry. Swedish University of Agricultural Sciences Uppsala, Sweden, pp 3-17 [in Swedish]

IPCC [Intergovernmental Panel on Climate Change] (2007) Climate Change 2007-The physical science basis. Contribution of Working Group I to the Fourth Assessment Report of the IPCC. Cambridge University Press, Cambridge, UK

Christensen JH, Christensen OB (2007) A summary of the PRUDENCE model projections of changes in European climate by the end of this century. Clim Change 81(Suppl 1):7-30. doi: 10.1007/s10584-006-9210-7

Coll L, Balandier P, Picon-Cochard C, Prévosto B, Curt T (2003) Competition for water between beech seedlings and surrounding vegetation in different light and vegetation competition conditions. Ann For Sci 60(7):593-600. doi:10.1051/forest:2003051 
Coll L, Balandier P, Picon-Cochard C (2004) Morphological and physiological responses of beech (Fagus sylvatica) seedlings to grass-induced belowground competition. Tree Physiol 24(1): $45-54$

Collet C, Löf M, Pagés L (2006) Root system development of oak seedlings analysed using an architectural model. Effects of competition with grass. Plant Soil 279(1/2):367-383. doi: 10.1007/s11104-005-2419-9

Curt T, Coll L, Prévosto B, Balandier P, Kunstler G (2005) Plasticity in growth, biomass allocation and root morphology in beech seedlings as induced by irradiance and herbaceous competition. Ann For Sci 62:51-60. doi:10.1051/forest:2004092

Davies RJ (1988) Sheet mulching as an aid to broadleaved tree establishment II. Comparison of various sizes of black polythene mulch and herbicide treated spots. Forestry 61(2):107-124. doi: 10.1093/forestry/61.2.89

De Kroon H, Mommer L (2006) Root foraging theory put to the test. Trends Ecol Evol 21:13-116. doi:10.1016/j.tree.2005.11.021

Dey DC, Jacobs D, McNabb K, Miller G, Baldwin V, Foster G (2008) Artificial regeneration of major oak (Quercus) species in the eastern United States-a review of the literature. For Sci 54(1):77-106

Drexhage M, Colin F (2001) Estimation root system biomass from breast-height diameters. Forestry 74(5):491-497. doi:10.1093/ forestry/74.5.491

Ellenberg H (1988) Vegetation ecology of central Europe. Cambridge University Press, Cambridge

Ericsson T, Rytter L, Vapaavuori E (1996) Physiology of carbon allocation in trees. Biomass Bioenergy 11:115-127. doi: 10.1016/0961-9534(96)00032-3

FAO (1988) FAO/Unesco soil map of the world. Revised legend, with corrections and updates. World Soil Resources Report 60, FAO Rome, Italy

Finney DJ (1941) On the distribution of a variable whose logarithm is normally distributed. J R Stat Soc B 7:55-161

Gemmel P, Nilsson U, Welander T (1996) Development of oak and beech seedlings planted under varying shelterwood densities and with different site preparation methods in southern Sweden. New For 12:141-161. doi:10.1007/BF00036626

Grime JP (1979) Plant strategies and vegetation processes. Wiley, Chichester

Grime JP, Mackey JML (2002) The role of plasticity in resource capture by plants. Evol Ecol 16(3):299-307. doi:10.1023/A:101 9640813676

Hallsby G, Örlander G (2004) A comparison of mounding and inverting to establish Norway spruce on podzolic soils in Sweden. Forestry 77(2):107-117. doi:10.1093/forestry/77.2.107

Harmer R, Robertson M (2003) Seedling root growth of six broadleaved tree species grown in competition with grass under irrigated nursery conditions. Ann For Sci 60(7):601-608. doi: 10.1051/forest:2003052

Hawkins C, Letchford T, Krasowski M (1995) Artificial regeneration of spruce on cold, wet soil-10 years along. Water Air Soil Pollut 82(1/2):115-124. doi:10.1007/BF01182825

Hoffmann CW, Usoltsev VA (2001) Modelling root biomass distribution in Pinus sylvestris forests of the Turgai Depression of Kazakhstan. For Ecol Manage 149(1/3):103-114. doi: 10.1016/S0378-1127(00)00548-X

Keyes MR, Grier CC (1981) Above- and below-ground net production in 40-year-old Douglas-fir stands on low and high productivity sites. Can J For Res 11(3):599-605. doi:10.1139/x81-082

Knapp BO,Wang GG, Walker JL, van Lear DH (2006) Can root biomass of white oak advance regeneration be reliably predicted from diameter and height? Gen Tech Rep SRS-92. Department of Agriculture, Forest Service, Southern Research Station, Asheville/NC, US, p 579
Koca D, Smith B, Sykes MT (2006) Modelling regional climate change effects on potential natural ecosystems in Sweden. Clim Change 78(2/4):381-406. doi:10.1007/s10584-005-9030-1

Larsen JB (1995) Ecological stability of forests and sustainable silviculture. For Ecol Manage 73(1/3):85-96. doi:10.1016/03781127(94)03501-M

Le Goff N, Ottorini J-M (2001) Root biomass and biomass increment in a beech (Fagus sylvatica L.) stand in North-East France. Ann For Sci 58(1):1-13. doi:10.1051/forest:2001104

Leckebusch GC, Koffi B, Ulbrich U, Pinto JG, Spangehl T, Zacharias S (2006) Analysis of frequency and intensity of European winter storm events from a multi-model perspective, at synoptic and regional scales. Clim Res 31(1):59-74. doi:10.3354/cr031059

Leuschner C, Hertel D, Schmid I, Koch O, Muhs A, Hölscher D (2004) Stand fine root biomass and fine root morphology in oldgrowth beech forests as a function of precipitation and soil fertility. Plant Soil 258(1):43-56. doi:10.1023/B:PLSO.0000016508.20173 .80

Löf M (2000) Establishment and growth in seedlings of Fagus sylvatica and Quercus robur: Influence of interference from herbaceous vegetation. Can J For Res 30(6):855-864. doi: 10.1139/cjfr-30-6-855

Löf M, Rydberg D, Bolte A (2006) Mounding site preparation for forest restoration: Survival and growth response in Quercus robur L. seedlings. For Ecol Manage 232(1/3):19-25. doi: 10.1016/j.foreco.2006.05.003

Ludovici KH (2008) Compacting Coastal Plain soils change midrotation loblolly pine allometry by reducing root biomass. Can J For Res 38(8):2169-2176. doi:10.1139/X08-060

Luterbacher J, Dietrich D, Xoplaki E, Grosjean M, Wanner H (2004) European seasonal and annual temperature variability, trends, and extremes since 1500. Science 303(5663):1499-1502

Lyr H (1996) Effect of root temperature on growth parameters of various European tree species. Ann For Sci 53(2/3):317-323. doi:10.1051/forest:19960214

Lyr H, Garbe V (1995) Influence of root temperature on growth of Pinus sylvestris, Fagus sylvatica, Tilia cordata and Quercus robur. Trees 9(4):220-223. doi:10.1007/BF00195276

Machado J-L, Walters MB, Reich PB (2003) Below-ground resources limit seedling growth in forest understories but do not alter biomass distribution. Ann For Sci 60(4):319-330. doi:10.1051/ forest:2003023

McConnaughay KDM, Coleman JS (1999) Biomass allocation in plants: ontogeny or optimality? A test along three resource gradients. Ecology 80(8):2581-2593. doi:10.1890/0012-9658 (1999)080[2581:BAIPOO]2.0.CO;2

Muukkonen P, Mäkipää R (2006) Biomass equations for European trees: addendum. Silva Fennica 40(4):763-773

Nielsen CCN, Mackenthun G (1991) Die horizontale Variation der Feinwurzelintensität in Waldböden in Abhängigkeit von der Bestockungsdichte. Eine rechnerische Methode zur Bestimmung der „Wurzelintensitätsglocke” an Einzelbäumen. Allg Forst- u J Ztg 162(5/6):112-119 [in German with English summary]

Niklas KJ (2004) Plant allometry: is there a grand unifying theory? Biol Rev 79(4):871-889. doi:10.1017/S1464793104006499

Nilsson U, Örlander G (1999) Vegetation management on grassdominated clearcuts planted with Norway spruce in southern Sweden. Can J For Res 29(7):1015-1026. doi:10.1139/cjfr-29-71015

Örlander G, Gemmel P, Hunt J (1990) Site preparation: a Swedish overview. FRDA Report 105. BC Ministry of Forests, Victoria, Canada

Patterson WB, Adams JC (2003) Soil, hydroperiod and bedding effects on restoring bottomland hardwoods on flood-prone agricultural lands in North Louisiana, USA. Forestry 76(2): 181-188. doi:10.1093/forestry/76.2.181 
Paz H (2003) Root/shoot allocation and root architecture in seedlings: variation among forest sites, microhabitats, and ecological groups. Biotropica 35(3):318-332

Peichl M, Arain MA (2007) Allometry and partitioning of above- and belowground tree biomass in an age-sequence of white pine forests. For Ecol Manage 253:68-80. doi:10.1016/j.foreco.2007. 07.003

Pennanen T, Heiskanen J, Korkama T (2005) Dynamics of ectomycorrhizal fungi and growth of Norway spruce seedlings after planting on a mounded forest clearcut. For Ecol Manage 213(1/3):243-252. doi:10.1016/j.foreco.2005.03.044

Picon-Cochard C, Coll L, Balandier P (2006) The role of belowground competition during early stages of secondary succession: the case of 3-year-old Scots pine (Pinus sylvestris L.) seedlings in an abandoned grassland. Oecologia 148(3):373-383. doi: 10.1007/s00442-006-0379-2

Reich PB (2002) Root-shoot relations: optimality in acclimation and adaptation or 'Emperor's new clothes'? In: Waisel Y, Eshel A, Kafkafi U (eds) Plant roots-the hidden half. Marcel Dekker, New York, pp 205-220

Santantonio D, Hermann RK, Overton WS (1977) Root biomass studies in forest ecosystems. Pedobiologia 17(1):1-31
Schär C, Vidale PL, Lüthi D, Frei C, Häberli C, Liniger M, Appenzeller C (2004) The role of increasing temperature variability in European summer heat waves. Nature 427:332336. doi: $10.1038 /$ nature 02300

Statsoft (2005) STATISTICA for Windows, version 7.1. Available from http://www.statsoft.com [accessed 09 December 2008]

Sutton RF (1993) Mounding site preparation: A review of European and North American experience. New For 7(2):151-192. doi: 10.1007/BF00034198

von Lüpke B, Spellmann H (1999) Aspects of stability, growth and natural regeneration in mixed Norway spruce-beech stands as a basis of silvicultural decisions. In: Olsthoorn AFM et al (eds) Management of mixed-species forest: Silviculture and economics. IBN Scientific Contributions 15, Wageningen, pp 245-267

Willoughby I, Balandier P, Bentsen NS, McCarthy N, Claridge J (2009) Forest vegetation management in Europe: current practice and future requirements. COST Office, Brussels

Wilson JB (1988) A review of evidence on the control on shoot: root ratio, in relation to models. Ann Bot 61(4):433-449

Zianis D, Muukkonen P, Mäkipää R, Mencuccini M (2005) Biomass and stem volume equations for tree species in Europe. Silva Fennica Monographs 4, Vantaa, Finland 